\title{
Identification and morphological characterization of marine actinomycetes as biocontrol agents of Fusarium solani in tomato
}

Identificación y caracterización morfológica de actinomicetos marinos como agentes de biocontrol de Fusarium solani en tomate

Identificação e caracterização morfológica de actinomicetos marinhos como agentes de biocontrole de Fusarium solani em tomate

Juan Antonio Torres-Rodriguez ${ }^{1}$ 징 (D)

Juan José Reyes-Pérez ${ }^{2}$ (중 (iD)

Thelma Castellanos ${ }^{1}$ (잉 (D)

Carlos Angulo ${ }^{1}$ (a) (D)

Evangelina Esmeralda Quiñones-Aguilar ${ }^{3}$ (징 (1)

Luis Guillermo Hernandez-Montiel ${ }^{1 *}$

Rev. Fac. Agron. (LUZ). 2022, 39(1): e223915

ISSN 2477-9407

DOI: https://doi.org/10.47280/RevFacAgron(LUZ).v39.n1.15
${ }^{1}$ Centro de Investigaciones Biológicas del Noroeste, La Paz, Baja California Sur, México.

${ }^{2}$ Universidad Técnica Estatal de Quevedo, Quevedo, Los Ríos, Ecuador.

${ }^{3}$ Centro de Investigación y Asistencia en Tecnología y Diseño del Estado de Jalisco, Guadalajara, México.

Received: 26-02-2021

Accepted: 09-07-2021

Published: 13-02-2022

\section{Crop Production}

Associate editor: Dra. Lilia Urdaneta

Keywords:

Streptomyces

Nocardiopsis

Antagonism

Solanum lycopersicum

\begin{abstract}
Fusarium spp. damages the roots of crops, its control is with synthetic fungicides, however, marine actinomycetes can be an option to the use of agrochemicals. The objective of this work was the identification and morphological characterization of marine actinomycetes as antagonists to Fusarium solani (Mart.) Sacc. Fusarium spp. was isolated from diseased tomato plants and mangrove sediment actinomycetes, both identified through taxonomic keys and molecular techniques. Eight isolates of Fusarium spp. were obtained, $\mathrm{H} 8$ being the most virulent and it was identified as $F$. solani. Thirty actinomycetes were isolated, of which only four inhibited the phytopathogen, being A19 the one that inhibited the fungus by $70 \%$ and was identified as Streptomyces sp. Marine actinomycetes may be an option for disease management in plants of agricultural interest.
\end{abstract}




\section{2-7| Rev. Fac. Agron. (LUZ). 2022, 39(1): e223915. January - March. ISSN 2477-9407.}

\section{Resumen}

Fusarium spp. daña a las raíces de los cultivos, su control es con fungicidas sintéticos, sin embargo, los actinomicetos marinos puede ser una opción al uso de agroquímicos. El objetivo de este trabajo fue la identificación y caracterización morfológica de actinomicetos marinos como antagonistas a Fusarium solani (Mart.) Sacc. Fusarium spp. fue aislado de plantas enfermas de tomate y los actinomicetos de sedimento de manglares, ambos se identificaron a través de claves taxonómicas y por técnicas moleculares. Se obtuvieron ocho aislamientos de Fusarium spp., siendo H8 el más virulento y fue identificado como F. solani. Se aislaron 30 actinomicetos, de los cuales solo cuatro inhibieron al fitopatógeno, siendo A19 el que inhibió en un 70\% al hongo y fue identificado como Streptomyces sp. Los actinomicetos marinos pueden ser una opción para el manejo de enfermedades en plantas de interés agrícola.

Palabras clave: Streptomyces, Nocardiopsis, antagonismo, Solanum lycopersicum.

\section{Resumo}

Fusarium spp. danifica as raízes das lavouras, seu controle é feito com fungicidas sintéticos, no entanto, os actinomicetos marinhos podem ser uma alternativa ao uso de agroquímicos. O objetivo deste trabalho foi a identificação e caracterização morfológica de actinomicetos marinhos como antagonistas a Fusarium solani (Mart.) Sacc. Fusarium spp. foi isolado a partir de tomateiros doentes e actinomicetos de sedimento de manguezais, ambos foram identificados por meio de chaves taxonômicas e técnicas moleculares. Foram obtidos oito isolados de Fusarium spp., sendo H8 o mais virulento e identificado como $F$. solani. Foram isolados 30 actinomicetos, dos quais apenas quatro inibiram o fitopatógeno, sendo A19 o que inibiu o fungo em $70 \%$ e foi identificado como Streptomyces sp. Os actinomicetos marinhos podem ser uma alternativa efetiva para o manejo de doenças em plantas de interesse agrícola.

Palavras-chave: Streptomyces, Nocardiopsis, antagonismo, Solanum lycopersicum.

\section{Introduction}

Tomato (Solanum lycopersicum L.), is an important crop in many regions of the world (Reyes-Pérez et al., 2018). This crop is susceptible to Fusarium spp. (Li et al., 2018), which, causes losses close to $80 \%$ of production (Akbar et al., 2016). The symptoms of plants with Fusarium spp. are; defolation, wilting and yellowing of leaves, and stem and root necrosis (Summerell et al., 2003). Fusarium spp. is controlled by synthetic fungicides such as: Mancozeb, Benomil, Carbendazim, among others (Gadhave et al., 2020), However, its application causes resistance to fungi and negative effects on the environment, human and animal health (Torres-Rodriguez et al., 2021). The search for alternatives to decrease the use of synthetic fungicides in agriculture is a priority worldwide (Maluin and Hussein, 2020).

The use ofactinomycetes as biocontrol agents towards phytopathogens is an alternative to the application of agrochemicals (Wang et al., 2018). Among the antagonistic mechanisms of actinomycetes are, antibiotics, siderophores, induction of host resistance, hydrolytic enzymes, among others (Gopalakrishnan et al.,
2021; Igarashi et al., 2021; Shen et al., 2021). Actinomycetes from terrestrial environments have been extensively studied, however, actinomycetes from marine environments are an understudied resource, which may be more efficient in controlling plant phytopathogens (Gong et al., 2018). Mangroves are ecosystems that are found in tropical and subtropical intertidal regions worldwide (Sangkanu et al., 2017). In these ecosystems, salinity and nutrient availability are highly variable, resulting in unique characteristics for the isolation of marine actinomycetes (Soldan et al., 2019). The objective of this work was the identification and morphological characterization of marine actinomycetes as biocontrol agents against Fusarium solani.

\section{Materials and methods}

Isolation and morphological identification of Fusarium spp.

Roots of tomato plants with Fusarium symptoms were collected from a commercial orchard located in El Carrizal, Baja California Sur, Mexico at $23^{\circ} 47^{\prime} 00^{\prime \prime}$ north latitude and $110^{\circ} 17^{\prime} 40^{\prime \prime}$ west latitude. Root pieces of $5 \mathrm{~mm}$ were disinfected with $2 \%$ sodium hypochlorite for $30 \mathrm{sec}$. They were washed with sterile distilled water and dried on absorbent paper. After, they were sown in Petri dishes with potatodextrose-agar (PDA, Difco 39 g. $\left.\mathrm{L}^{-1}\right)$ plus streptomycin $\left(0.1\right.$ g.L.- $\left.{ }^{-1}\right)$ and ampicillin $\left(0.1 \mathrm{~g} . \mathrm{L}^{-1}\right)$ and were incubated at $28^{\circ} \mathrm{C}$ for 6 days in complete darkness. Colonies were purified in Petri dishes with PDA and stored in slant tubes at $4{ }^{\circ} \mathrm{C}$. Fungal sporulation was determined (+++ abundant, ++ good, + moderate) (Sivakumar et al., 2018) and for macroscopic and microscopic identification the taxonomic keys of Summerell et al. (2003) were used.

\section{Pathogenicity test}

The concentration of each fungus was adjusted to $1.10^{6}$ conidia. $\mathrm{mL}^{-1}$ using a Neubaüer chamber. Tomato seedlings var. Saladet of 25 days, were immersed in conidia suspension of each isolation for $15 \mathrm{~min}$, prior to transplantation. As a control, plants were immersed in sterile distilled water. The plants were kept at $28{ }^{\circ} \mathrm{C}, 80 \%$ relative humidity (HR) and $12 \mathrm{~h}$ light in a growth chamber (Convairon ${ }^{\circledR}$ ) for 26 days. The severity of the disease was determined using the Marlatt scale et al. (1996)'; 1=plants without symptoms; $2=$ slight chlorosis and wilting; $3=$ =moderate chlorosis and wilting; 4=severe chlorosis and wilting; 5=dead plant. In addition, we quantified; height, stem diameter, root fresh weight and disease incidence (\%DI) (Saravanakumar et al., 2016) using the formula: $\% \mathrm{DI}=(\mathrm{PI} / \mathrm{TP}) \times 100 \%$, where $\mathrm{Pi}=$ number of infected plants and $\mathrm{TP}=$ total plants. Koch's postulates were tested. Five replicates (seedlings) per treatment were performed and the experiment was repeated twice.

Molecular identification a nd $p$ hylogenetic a nalysis of

\section{Fusarium spp.}

The extraction of DNA was carried out according to the methodology of Ochoa et al. (2007). The ITS1-5.8sITS2 region of rDNA was amplified using primers ITS1 (5' TCCGTAGGTGAACCCTGCGG 3') and ITS4 (5" TCCTCCGCTTATTGATATGC 3") (White et al., 1990). A thermal cycler (Applied Biosystems ${ }^{\circledR}$ ) was used with a denaturation period of 3 min at $95^{\circ} \mathrm{C}$, followed by 30 cycles (denaturation at $95^{\circ} \mathrm{C}$ for $1 \mathrm{~min}$, alignment for $30 \mathrm{~s}$ at $50^{\circ} \mathrm{C}$ and an extension of $1 \mathrm{~min}$ at $72{ }^{\circ} \mathrm{C}$ ), with a final extension at $72{ }^{\circ} \mathrm{C}$ for $10 \mathrm{~min}$. PCR products were sequenced in Genewiz ${ }^{\circledR}$. Phylogenetic analysis was performed with the MEGA 7 program (Kumar et al., 2018) with the maximum parsimony (MP) 
method, using the Kimura-2 parameter model (Tamura, 1992) and Gama distribution and 10,000 replicates (bootstrap). The MP tree was obtained using NNI (Nearest-Neighbor-Interchange).

\section{Isolation and identification of marine actinomycetes}

Sixteen samples of marine mangrove sediment were collected from four sampling sites in the Zacatecas estuary located in $\mathrm{La}$ Paz, Baja California Sur, Mexico at 249'30" north latitude and $110^{\circ} 25^{\prime} 37^{\prime \prime}$ west latitude. The collection was performed at a distance of $0-1,1-3$ and 3-5 $\mathrm{m}$ from the shoreline, at a depth of $25 \mathrm{~cm}$. Sediment samples were collected with a $10 \mathrm{~cm}$ diameter soil auger. The central portion of the samples was extracted with the help of a sterile spoon. The samples were dried at room temperature for 7 days. One g of sample was weighed and suspended in $9 \mathrm{~mL}$ of sterile seawater, it was incubated for $20 \mathrm{~min}$ in water bath at $60{ }^{\circ} \mathrm{C}$ and the solution was serially diluted to $10^{-6}$ (Palla et al., 2018). It was added $1 \mathrm{~mL}$ of each dilution to $15 \mathrm{~mL}$ of malt extract yeast agar medium (ISP2; malt extract $10 \mathrm{~g}$, yeast extract $4 \mathrm{~g}$, dextrose $4 \mathrm{~g}$, agar $20 \mathrm{~g}$, seawater $1 \mathrm{~L}, \mathrm{pH}$ 7.2). Plates were incubated at $28^{\circ} \mathrm{C}$ for 15 days. Each colony was purified in ISP2 and maintained in $20 \%$ glycerol at $-80^{\circ} \mathrm{C}$. Actinomycetes were identified with the keys of Shirling and Gottlieb (1966) and Gram staining (Duraipandiyan et al., 2010).

In vitro antagonism of marine actinomycetes vs. $F$. solani

A $0.5 \mathrm{~cm}$ disc of each actinomycete grown in ISP2 was placed in Petri dishes with PDA $1 \mathrm{~cm}$ from the edge of the plate and in the center a $0.5 \mathrm{~cm}$ disc of $F$. solani from a 7-day culturein PDA. A group of Petri dishes were inoculated with a reference strain of terrestrial origin cataloged as ED48 of Streptomyces sp. provided by the Centro de Investigación y Asistencia en Tecnología y Diseño del Estado de Jalisco, Mexico. Another group was inoculated with the phytopathogen plus the fungicide Carbendazim $\left(6 \mathrm{mg} \cdot \mathrm{mL}^{-1}\right)$ and another group was inoculated only with $F$. solani. The plates were incubated for 10 days at $28{ }^{\circ} \mathrm{C}$. The percentage of radial growth inhibition (RGPI, \%) of the fungus was determined with the formula: $[(\mathrm{R} 1-\mathrm{R} 2) / \mathrm{R} 1] \times 100 \%$ where $\mathrm{R} 1=$ radial growth of $F$. solani on the control plate and $\mathrm{R} 2=$ growth of $F$. solani in the direction towards the actinomycete colony (Azadeh et al., 2010). Five plates per treatment were used and the experiment was repeated twice.

\section{Antimicrobial activity in actinomycete supernatants}

Each actinomycete was cultivated in ISP2 at $30{ }^{\circ} \mathrm{C}$ for 7 days. After, $5 \mathrm{~mL}$ of sterile water were added and the spores were scraped and transferred to a $250 \mathrm{~mL}$ Erlenmeyer flask containing $50 \mathrm{~mL}$ of starch casein broth and incubated at $150 \mathrm{rpm}$ and $28{ }^{\circ} \mathrm{C}$ for 2 days. The cells were harvested, washed and re-suspended in $25 \mathrm{~mL}$ of sterile saline solution, subsequently, $10 \mathrm{~mL}$ of each inoculum was deposited in a $250 \mathrm{~mL}$ flask containing $100 \mathrm{~mL}$ of nutrient broth (millet $10 \mathrm{~g} . \mathrm{L}^{-1}$, glucose 10 g.L $\mathrm{L}^{-1}, \mathrm{CaCO}_{3} 2$ g.L $\mathrm{L}^{-1}, \mathrm{NaCl} 2.5$ g.L $\mathrm{L}^{-1}$, peptone 3 g.L $\mathrm{L}^{-1}, \mathrm{pH}$ 7.2-7.4) and incubated at $150 \mathrm{rpm}$ and $28^{\circ} \mathrm{C}$ for 12 days. The medium was centrifuged at $8000 \mathrm{x}$ g. for $20 \mathrm{~min}$ at $4{ }^{\circ} \mathrm{C}$, the supernatant was passed through a $0.22 \mu \mathrm{m}$ membrane filter and stored at $4{ }^{\circ} \mathrm{C}$. It was placed $1 \mathrm{~mL}$ of the supernatant from each actinomycete on a sensidisc $1 \mathrm{~cm}$ from the edge of the Petri dishes with PDA and a disk of $F$. solani was placed in the center. One group of Petri dishes was inoculated with strain ED48, another group was inoculated with the phytopathogen plus the fungicide Carbendazim (6 mg.mL-1) and another group was inoculated only with $F$. solani. The percentage of radial growth inhibition (RGPI, \%) of the fungus was determined with the formula: [(R1-R2)/R1] $\times 100 \%$ where R1=radial growth of $F$. solani on the control plate and $\mathrm{R} 2=$ growth of $F$. solani in the direction towards the actinomycete colony (Azadeh et al., 2010). Five plates per treatment were used and the experiment was repeated twice.

Molecular identification and phylogenetic analysis of marine actinomycetes

DNA was extracted using the modified Ochoa method et al. (2007). PCR amplification of the 16S rRNA gene sequence was performed using primers 27f (5'-AGAGTTTGATCCTGGCTCAG-3') and 1492r (5'-GGTTACCTTGTTACGACTT-3') (Wang et al., 2018). A thermal cycler (Applied Biosystems ${ }^{\circledR}$ ) was used with a denaturation period of $3 \mathrm{~min}$ at $98^{\circ} \mathrm{C}$, followed by 30 cycles (denaturation at 94 ${ }^{\circ} \mathrm{C}$ for $1 \mathrm{~min}$, alignment for $1 \mathrm{~min}$ at $52^{\circ} \mathrm{C}$ and an extension of $1 \mathrm{~min}$ at $72{ }^{\circ} \mathrm{C}$ ), with a final extension at $72{ }^{\circ} \mathrm{C}$ for $10 \mathrm{~min}$. PCR products were sequenced in Genewiz ${ }^{\circledR}$. Phylogenetic analyses were performed with the MEGA 7 program (Kumar et al., 2018) by the neighborjoining method using the Tamura-3 parameter model (Tamura, 1992) and Gama distribution and 10,000 repeats (bootstrap).

\section{Statistical analysis}

Data were analyzed by one-way analysis of variance method (ANOVA) using STATISTICA 10.0 software (software StatSoft, Tulsa, OK) and Fisher's LSD test was used $(\mathrm{P}<0.05)$ for separation of means.

\section{Results and discussion}

\section{Isolation and identification of Fusarium species}

Eight isolates were obtained: H1, H2, H3, H4, H5, H6, H7 and $\mathrm{H} 8$ of Fusarium spp. that presented different morphological characteristics, related to color, sporulation and mycelium (table 1).

According to Summerell et al. (2003) variability in morphology is common among Fusarium species. Choi et al. (2018) report Fusarium spp. colonies with diverse shapes, textures and colors. Duarte Leal et al. (2016) observed red, violet, salmon and yellow Fusarium spp. isolates. Macroconidia showed semi-curved, straight and slender shapes, with 3 to 5 septa, with a blunt or papillate apical cell type and foot-shaped basal cell or light notch. Microconidia were reniform and fusiform in shape (table 2). Differences were found among macroconidia and chlamydospores formed by the eight isolates, according to Murugan et al. (2020) and Sivakumar et al. (2018), there is variability among reproductive structures of Fusarium species.

\section{Pathogenicity of Fusarium spp.}

Of the eight Fusarium spp. isolates, only H3, H6, H7 and H8 were pathogenic, observing 100\% incidence in plants (table 3). Control plants showed the greatest height, stem diameter and root fresh weight because there is a relationship between Fusarium spp. pathogenicity with decreased plant growth (Chang et al., 2018). It has been reported that there is difference in virulence among isolates of Fusarium spp. (Murugan et al., 2020). In this regard, Nirmaladevi et al. (2016) observed variation in virulence of Fusarium spp. isolates, $45 \%$ were highly virulent and $30 \%$ were moderately virulent. The pathogenicity of Fusarium spp. is mediated by the action of lytic enzymes (endopolygalacturonase, exopolygalacturonase, endoxylanase and endopectate lyase) that depolymerize all cell wall components, such as cellulose, pectins and proteins (extensins). In addition, these enzymes serve to inactivate the plant's defense protein components, such as chitinase and $\beta$-1,3-glucanase (Roncero et al., 2000). 
4-7| Rev. Fac. Agron. (LUZ). 2022, 39(1): e223915. January - March. ISSN 2477-9407.

Table 1. Morphological characteristics of Fusarium spp. isolated from roots of Solanum lycopersicum L., in Baja California Sur, Mexico.

\begin{tabular}{|c|c|c|c|}
\hline Isolation & Color & Sporulation & Mycelium \\
\hline $\mathrm{H} 1$ & Gray & + & Sparse,white, aerial mycelium \\
\hline $\mathrm{H} 2$ & Light yellow & + & $\begin{array}{l}\text { Abundant, white, cottony } \\
\text { aerial mycelium }\end{array}$ \\
\hline $\mathrm{H} 3$ & White to cream & ++ & $\begin{array}{c}\text { Sparse, white, cottony, hyaline, } \\
\text { aerial mycelium }\end{array}$ \\
\hline $\mathrm{H} 4$ & White to cream & +++ & $\begin{array}{l}\text { Dense, white, cottony, hyaline, } \\
\text { aerial mycelium }\end{array}$ \\
\hline H5 & Light yellow & +++ & $\begin{array}{l}\text { Abundant, white, cottony } \\
\text { aerial mycelium }\end{array}$ \\
\hline H6 & Pale violet & +++ & $\begin{array}{l}\text { Abundant, white pinkish, } \\
\text { floccus, aerial mycelium }\end{array}$ \\
\hline H7 & Dark violet & +++ & $\begin{array}{l}\text { Abundant, white pinkish, } \\
\text { floccus, aerial mycelium }\end{array}$ \\
\hline H8 & Brown yellow & +++ & $\begin{array}{l}\text { Abundant, white, cottony, } \\
\text { hyaline, aerial mycelium }\end{array}$ \\
\hline
\end{tabular}

Table 2. Characteristics of the reproductive structures of Fusarium spp. isolation.

\begin{tabular}{|c|c|c|c|c|c|c|c|}
\hline \multirow[b]{2}{*}{ Isolation } & \multicolumn{4}{|c|}{ Macroconidia } & \multicolumn{2}{|c|}{ Microconidia } & \multirow[b]{2}{*}{ chlamydospore } \\
\hline & Shape & Septum & Apical cell & $\begin{array}{c}\text { Basal } \\
\text { cell }\end{array}$ & Shape & Septum & \\
\hline $\mathrm{H} 1$ & Semicurve & 3 & Blunt & Foot shape & Reniform & 0 & Paired, smooth wall \\
\hline $\mathrm{H} 2$ & Straight, slender & $3-4$ & Blunt & Light notch & Reniform & $0-1$ & ------------ \\
\hline H3 & Semicurve & 3 & Blunt & Foot shape & Reniform & 0 & ------------- \\
\hline $\mathrm{H} 4$ & $\begin{array}{c}\text { Dorsiventral } \\
\text { curvature }\end{array}$ & $4-5$ & Narrow & Foot shape & Reniform & 0 & Paired, smooth wall \\
\hline H5 & Semicurve & 3 & Blunt & Light notch & Reniform & $0-1$ & Simple warty \\
\hline H6 & Dorsiventralcurvature & $3-5$ & Papillate & Foot shape & $\begin{array}{l}\text { Reniform, } \\
\text { fusiform }\end{array}$ & 0 & Paired, smooth wall \\
\hline $\mathrm{H} 7$ & Dorsiventral curvature & $3-5$ & Papillate & Foot shape & $\begin{array}{l}\text { Reniform, } \\
\text { Fusiform }\end{array}$ & 0 & Paired, smooth wall \\
\hline $\mathrm{H} 8$ & Semicurve & $3-5$ & Blunt & Foot shape & $\begin{array}{l}\text { Reniform, } \\
\text { fusiform }\end{array}$ & $0-1$ & Paired, smooth wall \\
\hline
\end{tabular}


Table 3. Severity of Fusarium spp. isolation and their effect on growth variables in tomato.

\begin{tabular}{ccccc}
\hline Treatment & Severity $^{*}$ & Height $(\mathrm{mm})$ & $\begin{array}{c}\text { Stem } \\
\text { diameter } \\
(\mathrm{mm})\end{array}$ & $\begin{array}{c}\text { Root fresh } \\
\text { weight }(\mathrm{mg})\end{array}$ \\
\hline Control & 0 & $233.6 \pm 11.3^{\mathrm{a}}$ & $4.1 \pm 0.3^{\mathrm{a}}$ & $55.0 \pm 4.3^{\mathrm{a}}$ \\
H3 & 3 & $166.4 \pm 11.1^{\mathrm{b}}$ & $2.2 \pm 0.4^{\mathrm{b}}$ & $32.4 \pm 3.7^{\mathrm{b}}$ \\
H6 & 4 & $125.2 \pm, 12.4^{\mathrm{c}}$ & $1.6 \pm 0.3^{\mathrm{c}}$ & $28.4 \pm 3.9^{\mathrm{c}}$ \\
H7 & 4 & $129.1 \pm 11.7^{\mathrm{c}}$ & $1.6 \pm 0.3^{\mathrm{c}}$ & $27.8 \pm 4.1^{\mathrm{c}}$ \\
H8 & 5 & $75.4 \pm 12.8^{\mathrm{d}}$ & $1.2 \pm 0.4^{\mathrm{d}}$ & $18.4 \pm 3.8^{\mathrm{d}}$ \\
\hline
\end{tabular}

a, b, c, d Different letters between columns differ significantly according to Fisher $(\mathrm{P}<0.05)$. Severity*: $1=$ plants without symptoms; $2=$ slight chlorosis and wilting; $3=$ moderate chlorosis and wilting; $4=$ severe chlorosis and wilting; $5=$ dead plant.

\section{Molecular identification and phylogenetic analysis of} Fusarium sp.

The size of the PCR product of the ITS1-5.8s-ITS2 region of isolate $\mathrm{H} 8$ was $550 \mathrm{bp}$. Its sequence was $100 \%$ identical to $F$. solani. In the phylogenetic analysis, the ITS1-5.8s-ITS2 sequences were grouped with $F$. solani as a single group (figure 1). Morphology of the fungi allows their identification to the genus (Summerell et al., 2003), however, the similarities in the reproductive structures make their identification at the species level complex (Al-Fadhal et al., 2019). Singha et al. (2016) observed differences in morphological and molecular identification (ITS region) of Fusarium species. The ITS region is studied for fungal identification due to the species specificity of this region and provides better resolution at the subspecies level and therefore, sequence analysis is a superior option for phylogenetic studies (Okubara et al., 2005). The dendogram indicated that the sequence obtained in the present study clustered with other $F$. solani sequences. The colony morphology and sequence of the ITS region of isolate H8, identified it as F. solani.

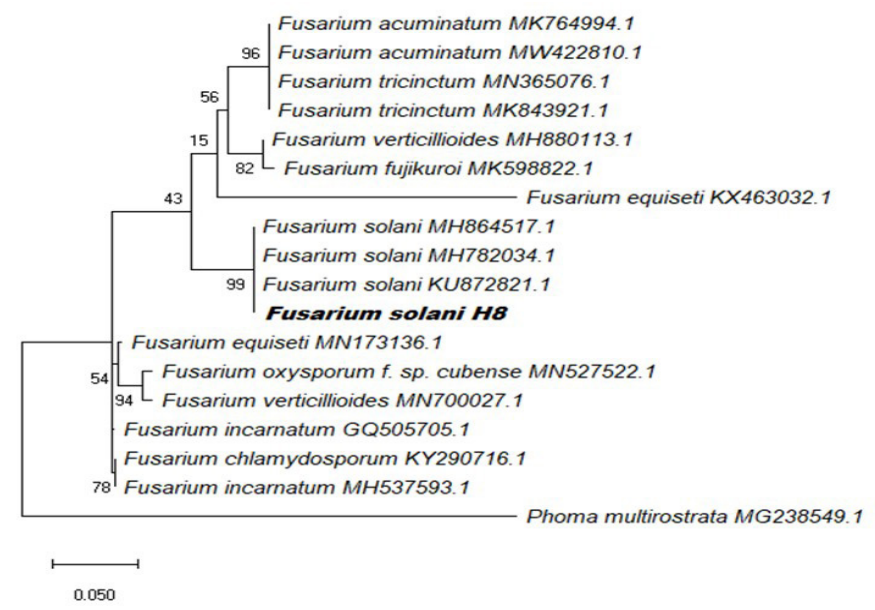

Figure 1. Phylogenetic tree based on the ITS1-5.8s-ITS2 region of the $\mathbf{H 8}$ fungus isolated from tomato plants diseased by Fusarium spp. Bootstrap values are indicated as percentages over the nodes in this analysis $(10,000$ bootstrap).

Isolation and morphological identification of marine actinomycetes

Thirty isolates of actinomycetes that showed differences in mycelium, color, texture, shapewere obtained and were determined as Gram-positive bacteria (table 4). The determination of the characteristics of actinomycetes is important in the evaluation of the diversity of the microbial community, these can be differentiated based on texture, color, shape and elevation of colonies, among others (Rathore et al., 2019). The morphological results are similar to those reported by Goudjal et al. (2014), who obtained isolates with coloration ranging from yellowish white to brownish gray. Mangrove ecosystems are one of the habitats with a large number of organisms (Barka et al., 2016; Sangkanu et al., 2017). Only 1\% of the species in these ecosystems have been studied and there is a lack of knowledge about their ecological role and potential application, especially in agriculture (Palla et al., 2018; Ameen et al., 2021).

Table 4. Morphological characteristics of marine actinomycetes isolation.

\begin{tabular}{|c|c|c|c|c|}
\hline Isolation & Mycelium & Mycelium color & Texture & Colony \\
\hline A1 & Substrate & Yellowish gray & Wrinkled/coarse & Irregular \\
\hline A2 & Substrate & Pale yellow & Folded & Irregular \\
\hline A3 & Substrate & Yellowish gray & Wrinkled & Circular \\
\hline A4 & Aerial & Dark yellow & Creamy & Irregular \\
\hline A5 & Substrate & Yellowish gray & Wrinkled & Irregular \\
\hline A6 & Substrate & Light yellow & Wrinkled & Circular \\
\hline A7 & Substrate & Pale yellow & Folded & Circular \\
\hline A8 & Aerial & Pale yellow & Creamy & Punctiform \\
\hline A9 & Substrate & Light yellow & Wrinkled & Irregular \\
\hline A 10 & Substrate & Gray & Wrinkled & Irregular \\
\hline A11 & Substrate & Red & Creamy & Irregular \\
\hline $\mathrm{A} 12$ & Substrate & Yellow & Creamy & Irregular \\
\hline A 13 & Substrate & Light yellow & Creamy & Circular \\
\hline A 14 & Substrate & Dark brown & Wrinkled & Irregular \\
\hline A 15 & Substrate & Light pink & Creamy & Circular \\
\hline A 16 & Substrate & Light gray & Creamy & circular \\
\hline A 17 & Aerial & Dark gray & Creamy & Irregular \\
\hline A 18 & Aerial & Yellow & Creamy & Circular \\
\hline A 19 & Substrate & Yellow & Folded & Rhizoid \\
\hline A 20 & Aerial & Dark gray & Creamy & Irregular \\
\hline A 21 & Substrate & Light yellow & Creamy & Punctiform \\
\hline A 22 & Substrate & White & Creamy & Circular \\
\hline A 23 & Aerial & Yellow & Creamy & Punctiform \\
\hline A 24 & Substrate & Light pink & Creamy & Circular \\
\hline A 25 & Aerial & Dark yellow & Creamy & Irregular \\
\hline A 26 & Aerial & Dark gray & Creamy & Irregular \\
\hline A 27 & Substrate & Light yellow & Wrinkled & Circular \\
\hline A 28 & Aerial & Yellow & Creamy & Circular \\
\hline A 29 & Substrate & Yellow & Creamy & Circular \\
\hline A 30 & Substrate & Yellow & Folded & Circular \\
\hline
\end{tabular}

In vitro antagonism tests of marine actinomycetes against F. solani

Only four isolates showed antifungal activity (A20, A19, A18 and A15) against $F$. solani. A19 showed the highest antagonistic activity with a RGPI (Percentage of radial growth inhibition) of 
$72 \%$, which did not show difference with the synthetic fungicide. A15 showed the lowest RGPI with 39.53\% (figure 2a). Only A19 and A18 showed an effect on supernatant. A19 showed a RGPI of $44.92 \%$ and it did not show difference with ED48 (figure $2 b$ ).
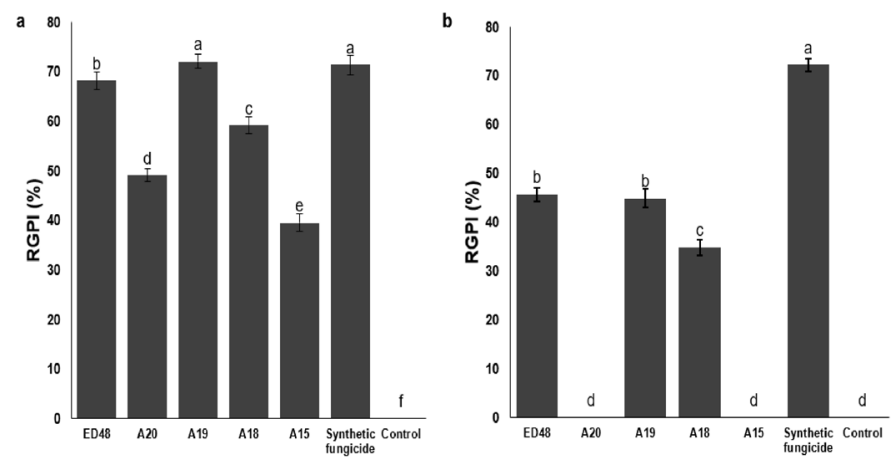

Figure 2. In vitro antagonism of marine actinomycetes against F. solani. (a) Percentage of radial growth inhibition (RGPI) of actinomycetes against F. solani. (b) RGPI of actinomycetes supernatants against F. solani. Synthetic fungicide $=$ Carbendazim $\left(6 \mathrm{mg} \cdot \mathrm{mL}^{-1}\right) . \mathrm{n}=5 . \pm$ Standard Desviation. Equal letters in the columns do not differ significantly according to Fisher $(\mathrm{P}<0.05)$.

Actinomycetes from terrestial environments have been widely studied as biocontrol agents against phytopathogens (Benhadj et al., 2019). Therefore, isolation of actinomycetes from under-researched environments such as marine, glacial, saline, among others, will provide new biocontrol agents that can be applied in agriculture (Gong et al., 2018). Several species of Streptomyces have been used for the control of soil phytopathogens (Ling et al., 2020). Among the bioactive compounds they produce are: hydrolytic enzymes and actinomycins, which are antibiotics belonging to the chromopeptide lactone family that function as growth inhibitors (Chen et al., 2020). Nocardiopsis species exhibit antifungal activity against Fusarium species and produce various antimicrobial metabolites (Intra et al., 2011). The antagonistic activity of actinomycetes against plant pathogens depends on their ability to produce hydrolytic enzymes, antifungal metabolites, competition for nutrients, siderophores, among others (Igarashi et al., 2021; Shen et al., 2021; Vurukonda et al., 2018).

Molecular identification and phylogenetic analysis of marine actinomycetes

PCR products of the $16 \mathrm{~S}$ region were $1500 \mathrm{bp}$ in size. A19 and A20 were $99.56 \%$ similar to Streptomyces sp. and A15 and A18 to Nocardiopsis lucentensis $(99.50 \%)$. Phylogenetic analysis of the $16 \mathrm{~S}$ gene of A20 grouped it together with Streptomyces griseoflavus and A19 was grouped in the Streptomyces sp. clade. Phylogenetic analysis of A18 and A15 grouped them with Nocardiopsis lucentensis (figure 3).

The 16s rRNA gene is found in prokaryotic organisms and archaeobacteria and its eukaryotic counterpart exists, its size is $1500 \mathrm{bp}$ and it presents a high degree of conservation to distinguish between taxa, even at deep taxonomic levels (Clarridge, 2004). Based on colony morphology and 16s rRNA gene sequence, A20 was identified as Streptomyces griseoflavus, isolate A19 as Streptomyces sp. and isolates A15 and A18 as Nocardiopsis lucentensis.

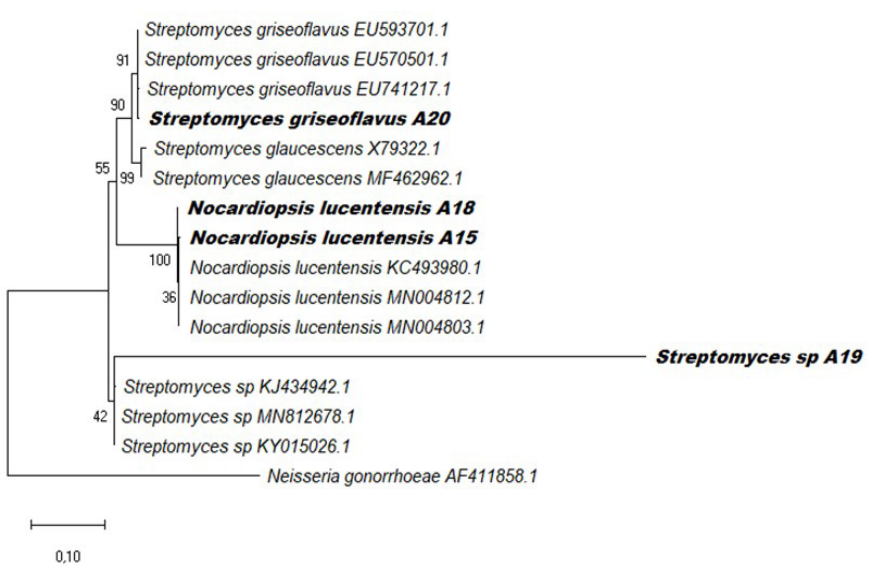

Figure 3. Phylogenetic tree based on the 16S rRNA gene of actinomycetes A20, A19, A18 and A15 isolated from marine environments. Bootstrap values are given as percentages over the nodes in this analysis $(10,000$ bootstrap).

\section{Conclusions}

Thirty isolates of marine actinomycetes were obtained, of which Streptomyces sp., S. griseoflavus and Nocardiopsis lucentensis showed in vitro antifungal activity against $F$. solani. Streptomyces $\mathrm{sp}$. showed the highest antifungal activity against the phytopathogenic fungus with a (RGPI) of $72 \%$. Marine environments are a new source for isolation of microorganisms that can be used as biocontrol agents against phytopathogens.

\section{Acknowledgement}

J. A. Torres-Rodriguez thanks the Consejo Nacional de Ciencia y Tecnología-México for Grant 2021910046. J. J. Reyes-Pérez and L. G. Hernandez-Montiel were thesis co-directors.

\section{Literature cited}

Akbar, K., Abbasi, F. M., Sajid, M., Ahmad, M., Khan, Z. U., Aziz-Ud-Din, and Ali, H. (2016). Marker-assisted selection and pyramiding of I1 and Ph3 genes for multiple disease resistance in tomato through PCR analysis. International Journal of Biosciences, 9(3), 108-113. http://dx.doi. org/10.12692/ijb/9.3.108-113

Al-Fadhal, F. A., AL-Abedy, A. N. and Alkhafije, D. A. (2019). Isolation and molecular identification of Rhizoctonia solani and Fusarium solani isolated from cucumber (Cucumis sativus L.) and their control feasibility by Pseudomonas fluorescens and Bacillus subtilis. Egyptian Journal of Biological Pest Control, 29(1), 1-11. https://doi.org/10.1186/ s41938-019-0145-5

Ameen, F., AlNadhari, S. and Al-Homaidan, A. A. (2021). Marine microorganisms as an untapped source of bioactive compounds. Saudi Journal of Biological Sciences, 28(1), 224-231. https://doi. org/10.1016/j.sjbs.2020.09.052

Azadeh, B. F., Sariah, M. and Wong, M. Y. (2010). Characterization of Burkholderia cepacia genomovar I as a potential biocontrol agent of Ganoderma boninense in oil palm. African Journal of Biotechnology, 9(24), 3542-3548.

Barka, E. A., Vatsa, P., Sanchez, L., Gaveau-Vaillant, N., Jacquard, C., Klenk, H. P., Clément, C., Ouhdouch, Y. and van Wezel, G. P. (2016). Taxonomy, physiology, and natural products of Actinobacteria. Microbiology and Molecular Biology Reviews: MMBR, 80(1), 1-43. https://doi. org/10.1128/MMBR.00019-15

Benhadj, M., Gacemi-Kirane, D., Menasria, T., Guebla, K. and Ahmane, Z. (2019). Screening of rare actinomycetes isolated from natural wetland ecosystem (Fetzara Lake, northeastern Algeria) for hydrolytic enzymes and antimicrobial activities. Journal of King Saud UniversityScience,31(4), 706-712. https://doi.org/10.1016/j.jksus.2018.03.008 
Chang, X., Dai, H.,Wang, D., Zhou, H., He, W., Fu, Y., Ibrahim, F., Zhou, Y., Gong, G., Shang, J., Yang, J.,Wu, X., Yong, T., Song, C. and Yang, W. (2018). Identification of Fusarium species associated with soybean root rot in Sichuan Province, China.European Journal of Plant Pathology, 151(3), 563-577. https://doi.org/10.1007/s10658-017-1410-7

Chen, Z., Ou, P., Liu, L. and Jin, X. (2020). Anti-MRSA activity of actinomycin $\mathrm{X} 2$ and collismycin a produced by Streptomyces globisporus WA52-37 from the intestinal tract of American cockroach (Periplaneta americana). Frontiers in Microbiology, 11, 555. https://doi.org/10.3389/ fmicb.2020.00555

Choi, H. W., Hong, S. K., Lee, Y. K., Kim, W. G. and Chun, S. (2018). Taxonomy of Fusarium fujikuroi species complex associated with bakanae on rice in Korea. Australasian Plant Pathology, 47(1), 23-34. https://doi. org/10.1007/s13313-017-0536-6

Clarridge, J. E. (2004). Impact of $16 \mathrm{~S}$ rRNA gene sequence analysis for identification of bacteria on clinical microbiology and infectious diseases. Clinical Microbiology Reviews, 17(4), 840-862. https://doi.org/10.1128/ CMR.17.4.840-862.2004

Duarte Leal, Y., Echevarría Hernández, A. y Martínez Coca, B. (2016). Identificación y caracterización de aislamientos de Fusarium spp. presentes en garbanzo (Cicer arietinum L.) en Cuba. Revista de Protección Vegetal, 31(3), 173-183. https://cutt.ly/qnva8A5

Duraipandiyan, V., Sasi, A. H., Islam, V. I. H.,Valanarasu, M. and Ignacimuthu, S. (2010). Antimicrobial properties of actinomycetes from the soil of Himalaya. Journal de Mycologie Medicale, 20(1), 15-20. https://doi. org/10.1016/j.mycmed.2009.11.002

Gadhave, A. D., Patil, P. D., Dawale, M. B., Suryawnshi, A. P., Joshi, M. S. and Giri, V. V. (2020). In-vitro Evaluation of different fungicides and bioagents against Fusarium oxysporum f. sp. lycopersici. International Journal of Current Microbiology and Applied Sciences, 9(8), 3576-3584. https://doi.org/10.20546/ijcmas.2020.908.412

Gong, B., Chen, S., Lan, W., Huang, Y. and Zhu, X. (2018). Antibacterial and antitumor potential of actinomycetes isolated from mangrove soil in the Maowei Sea of the southern coast of China. Iranian Journal of Pharmaceutical Research, 17(4), 1339-1346. https://doi.org/10.22037/ ijpr.2018.2280

Gopalakrishnan, S., Srinivas, V., Naresh, N., Pratyusha, S., Ankati, S., Madhuprakash, J., Govindaraj, M. and Sharma, R. (2021). Deciphering the antagonistic effect of Streptomyces spp. and host-plant resistance induction against charcoal rot of sorghum. Planta, 253(2), 1-12. https:// doi.org/10.1007/s00425-021-03577-5

Goudjal, Y., Toumatia, O.,Yekkour, A., Sabaou, N., Mathieu, F. and Zitouni, A. (2014). Biocontrol of Rhizoctonia solani damping-off and promotion of tomato plant growth by endophytic actinomycetes isolated from native plants of Algerian Sahara. Microbiological Research, 169(1), 59-65. https://doi.org/10.1016/j.micres.2013.06.014

Igarashi, M., Sawa, R., Umekita, M., Hatano, M., Arisaka, R., Hayashi, C., Ishizaki, Y., Suzuki, M. and Kato, C. (2021). Sealutomicins, new enediyne antibiotics from the deep-sea actinomycete Nonomuraea sp. MM565M173N2. Journal of Antibiotics, 74,291-299. https://doi.org/10.1038/ s41429-020-00402-1

Intra, B., Mungsuntisuk, I., Nihira, T., Igarashi,Y. and Panbangred, W. (2011). Identifcation of actinomycetes from plant rhizospheric soils with inhibitory activity against Colletotrichum spp., the causative agent of anthracnose disease. BMC Research Notes,4, 98. https://doi.org/10.1186/1756-05004-98

Kumar, S., Stecher, G., Li, M., Knyaz, C. and Tamura, K. (2018). MEGA X: Molecular evolutionary genetics analysis across computing platforms. Molecular Biology and Evolution, 35(6), 1547-1549. https://doi. org $/ 10.1093 / \mathrm{molbev} / \mathrm{msy} 096$

Li, Y. T., Hwang, S. G., Huang, Y. M. and Huang, C. H. (2018). Effects of Trichoderma asperellum on nutrient uptake and Fusarium wilt of tomato. Crop Protection, 110, 275-282. https://doi.org/10.1016/j. cropro.2017.03.021

Ling, L., Han, X., Li, X., Zhang, X., Wang, H., Zhang, L., Cao, P., Wu, Y., Wang, X., Zhao, J. and Xiang, W. (2020). A Streptomyces sp. NEAU-HV9: Isolation, identification, and potential as a biocontrol agent against Ralstonia solanacearum of tomato plants. Microorganisms, 8(3), 351. https://doi.org/10.3390/microorganisms8030351

Maluin, F. N. and Hussein, M. Z. (2020). Chitosan-based agronanochemicals as a sustainable alternative in crop protection. Molecules, 25(7), 1611. https:// doi.org $/ 10.3390 /$ molecules 25071611

Marlatt, M. L., Correll, J. C., Kaufmann, P. and Cooper, P. E. (1996). Two genetically distinct populations of Fusarium oxysporum f. sp. lycopersici race 3 in the United States. Plant Disease, 80(12), 1336-1342. https://doi. org/10.1094/PD-80-1336

Murugan, L., Krishnan, N.,Venkataravanappa, V., Saha, S., Mishra, A. K., Sharma, B. K. and Rai, A. B. (2020). Molecular characterization and race identification of Fusarium oxysporum f. sp. lycopersici infecting tomato in India. 3 Biotech, 10, 486. https://doi.org/10.1007/s13205-020-02475-Z

Nirmaladevi, D., Venkataramana, M., Srivastava, R. K., Uppalapati, S. R., Gupta, V. K., Yli-Mattila, T., Tsui, K. M., Srinivas, C., Niranjana, S. R. and Chandra, N. S. (2016). Molecular phylogeny, pathogenicity and toxigenicity of Fusarium oxysporum f. sp. lycopersici. Scientific Reports, 6(1), 1-14. https://doi.org/10.1038/srep21367

Ochoa, J. L., Hernández-Montiel, L. G., Latisnere-Barragán, H., León de La Luz, J. L. and Larralde-Corona, C. P. (2007). Isolation and identification of pathogenic fungi from orange Citrus sinensis L. Osbeck cultured in Baja California Sur, México. Ciencia y Tecnología Alimentaria, 5(5), 352-359. https://doi.org/10.1080/11358120709487712

Okubara, P. A., Schroeder, K. L. and Paulitz, T. C. (2005). Real-time polymerase chain reaction: applications to studies on soilborne pathogens. Canadian Journal of Plant Pathology, 27(3), 300-313. https://doi. org/10.1080/07060660509507229

Palla, M. S., Guntuku, G. S., Muthyala, M. K. K., Pingali, S. and Sahu, P. K. (2018). Isolation and molecular characterization of antifungal metabolite producing actinomycete from mangrove soil. Beni-Suef University Journal of Basic and Applied Sciences, 7(2), 250-256. https://doi. org/10.1016/j.bjbas.2018.02.006

Rathore, D. S., Sheikh, M., Gohel, S. and Singh, S. P. (2019). Isolation strategies, abundance and characteristics of the marine actinomycetes of Kachhighadi, Gujarat, India. Journal of the Marine Biological Association of India, 61(1), 71-78. http://dx.doi.org/10.6024/jmbai.2019.61.1.2028-11

Reyes-Pérez, J. J., Luna-Murillo, R. A., Reyes-Bermeo, M. R.,Vázquez-Morán, V. F., Zambrano-Burgos, D. y Torres-Rodríguez, J. A. (2018). Efecto de los abonos orgánicos sobre la respuesta productiva del tomate (Solanum lycopersicum L). Revista de la Facultad de Agronomía de la Universidad del Zulia, 35(1), 26-39. https://cutt.ly/bnvsmtW

Roncero, M. I., Di Pietro, A., Ruiz-Roldán, M. C., Huertas-González, M. D., Garcia-Maceira, F. I., Méglecz, E., Jiménez, A., Caracuel, Z., SanchoZapatero, R., Hera, C., Gómez-Gómez, E., Ruiz-Rubio, M., GonzálezVerdejo, C. I. and Páez, M. J. (2000). Role of cell wall-degrading enzymes in pathogenicity of Fusarium oxysporum. Revista Iberoamericana de Micología, 17(1), S47-53

Sangkanu, S., Rukachaisirikul, V., Suriyachadkun, C. and Phongpaichit, S. (2017). Evaluation of antibacterial potential of mangrove sedimentderived actinomycetes. Microbial Pathogenesis, 1 12, 303-312. https:// doi.org/10.1016/j.micpath.2017.10.010

Saravanakumar, K., Yu, C., Dou, K., Wang, M., Li,Y. and Chen, J. (2016). Synergistic effect of Trichoderma-derived antifungal metabolites and cell wall degrading enzymes on enhanced biocontrol of Fusarium oxysporum f. sp. cucumerinum. Biological Control, 94, 37-46. https://doi. org/10.1016/j.biocontrol.2015.12.001

Shen, T., Lei, Y., Pu, X., Zhang, S. and Du, Y. (2021). Identification and application of Streptomyces microflavus G33 in compost to suppress tomato bacterial wilt disease.Applied Soil Ecology, 157, 103724. https://doi.org/10.1016/j. apsoil.2020.103724

Shirling, E. B. and Gottlieb, D. (1966). Methods for characterization of Streptomyces species. International Journal of Systematic and Evolutionary Microbiology, 16(3), 313-340. https://doi.org/10.1099/00207713-16-3313

Singha, I. M., Kakoty, Y., Unni, B. G., Das, J. and Kalita, M. C. (2016). Identification and characterization of Fusarium sp. using ITS and RAPD causing fusarium wilt of tomato isolated from Assam, North East India. Journal of Genetic Engineering and Biotechnology, 14(1), 99-105. https://doi.org/10.1016/j.jgeb.2016.07.001

Sivakumar, T., Balabaskar,P. and Sanjeevkumar, K. (2018). Variability in Fusarium oxysporum f. sp. lycopersici causing wilt of tomato. International Journal of Chemical Studies, 6(2), 3655-3659. https://cutt.ly/bnvsBL6

Soldan, R., Mapelli, F., Crotti, E., Schnell, S., Daffonchio, D., Marasco, R., Fusi, M., Borin, S. and Cardinale, M. (2019). Bacterial endophytes of mangrove propagules elicit early establishment of the natural host and promote growth of cereal crops under salt stress. Microbiological Research, 223, 33-43. https://doi.org/10.1016/j.micres.2019.03.008

Summerell, B. A., Salleh, B. and Leslie, J. F. (2003). A utilitarian approach to Fusarium identification. Plant Disease, 87(2), 117-128. https://doi. org/10.1094/PDIS.2003.87.2.117

Tamura, K. 1992. Estimation of the number of nucleotide substitutions when there are strong transition-transversion and $\mathrm{G}+\mathrm{C}$-content biases. Molecular Biology and Evolution, 9(4), 678-687. https://doi.org/10.1093/ oxfordjournals.molbev.a040752

Torres-Rodriguez, J. A., Reyes-Pérez, J. J.,Castellanos, T., Angulo, C., QuiñonesAguilar, E. E. and Hernandez-Montiel, L. G. (2021). A biopolymer with antimicrobial properties and plant resistance inducer against phytopathogens: Chitosan. Notulae Botanicae Horti Agrobotanici ClujNapoca, 49(1), 1-15. https://doi.org/10.15835/nbha49112231

Vurukonda, S. S. K. P., Giovanardi, D. and Stefani, E. (2018). Plant growth promoting and biocontrol activity of Streptomyces spp. as endophytes. In International Journal of Molecular Sciences, 19(4), 952. https://doi. org/10.3390/ijms 19040952

Wang, X., Zhang, M.,Gao, J., Pu, T., Bilal, M.,Wang,Y. and Zhang, X. (2018). Antifungal activity screening of soil actinobacteria isolated from Inner Mongolia, China. Biological Control, 127, 78-84. https://doi. org/10.1016/j.biocontrol.2018.07.007

White, T. J., Bruns, T., Lee, S. and Taylor, J. W. (1990). Amplification and direct sequencing of fungal ribosomal RNA genes for phylogenetics. Innis, M.A., D.H. Gelfand, J. J. Sninsky and T.J. White (Ed.), PCR protocols: a guide to methods and applications, (Vol. 18, pp. 315-322). Academic Press, 1990. Inc. New York. http://dx.doi.org/10.1016/B978-0-12-372180$8.50042-1$ 